\title{
Leukocyte Trafficking
}

National Cancer Institute

\section{Source}

National Cancer Institute. Leukocyte Trafficking. NCI Thesaurus. Code C19438.

The circulation of white blood cells from the blood stream to tissues or secondary

lymphoid organs, to the lymphatics, and back to the bloodstream via the thoracic duct. 